\title{
HUBUNGAN ANTARA PENGETAHUAN, SIKAP DAN PERILAKU PERAWAT DALAM MENGATASI STRES HOSPITALISASI PADA ANAK PRA SEKOLAH DI RUMAH SAKIT UMUM FITRI CANDRA WONOGIRI
}

\author{
Relationship between Knowledge, Attitude and Behavior of Nurses in Overcoming \\ Stress Hospitazation in Pre-school Children in Public Hospital Fitri Candra \\ Wonogiri
}

\author{
Ahmad Samsul Bahri ${ }^{1}$, Sri Sayekti Heni Sunaryanti ${ }^{2}$, Daryanti ${ }^{3}$ \\ ${ }^{1}$ STIKES Estu Utomo Boyolali, ${ }^{2}$ STIKES Mamba'ul 'Ulum Surakarta, \\ ${ }^{3}$ RS Fitri Candra Wonogiri \\ samm80055@gmail.com
}

\begin{abstract}
ABSTRAK
Latar Belakang: Hospitalisasi pada anak merupakan suatu proses yang terjadi karena suatu alasan yang direncanakan atau darurat sehingga mengharuskan anak untuk tinggal di rumah sakit. Pengetahuan, sikap dan perilaku perawat yang baik dalam mengatasi dampak hospitalisasi diharapkan dapat membantu mengatasi stres hospitalisasi pada anak.

Tujuan: Mengetahui hubungan antara pengetahuan, sikap dan perilaku perawat dalam mengatasi stres hospitalisasi pada anak pra sekolah di Rumah Sakit Umum Fitri Candra Wonogiri.

Metode: Metode penelitian adalah deskripsi kolerasi, pendekatan cross sectional. Sampel penelitian adalah 25 perawat Rawat Inap dan 25 pasien anak dengan hospitaslisasi. Teknik sampel menggunakan Sampling Jenuh. Instrumen penelitian menggunakan kuesioner pengetahuan, sikap dan perilaku, tingkat stres hospitalisasi menggunakan DASS. Analisis data menggunakan uji statistik Fisher exact dan Regresi linier berganda.

Hasil: Sebanyak 16 responden (64\%) dengan pengetahuan baik, 9 responden ((36\%) dengan pengetahuan kurang baik. Terdapat 18 responden (72\%) dengan sikakp positif, 7 responden $(28 \%)$ dengan sikap negatif. Terdapat 14 responden $(56 \%)$ dengan perilaku baik dan 11 responden (44\%) dengan perilaku kurang baik. Sebanyak 13 anak dengan stres ringan (52\%) dan 12 responden dengan stres sedang (48\%). Hasil uji Fisher exact hubungan pengetahuan dan stres hospitalisasi $\mathrm{p}=0,041$.

Hubungan sikap dan stres hospitalisasi diperoleh $\mathrm{p}=0,030$. Hubungan perilaku dan stress stres hospitalisasi diperoleh $\mathrm{p}=0,047$. Persamaan regresi linier berganda $\mathrm{Y}=39,573-0,629 \mathrm{X}_{1}-0,216 \mathrm{X}_{2}-0,709 \mathrm{X}_{3}$.

Kesimpulan : Ada hubungan antara pengetahuan, sikap dan perilaku perawat dalam mengatasi stres hospitalisasi pada anak pra sekolah. Faktor perilaku perawat merupakan faktor paling berpengaruh terhadap tingkat stres hospitalisasi anak pra sekolah.
\end{abstract}

Kata kunci: Pengetahuan, sikap, perilaku, stres hospitalisasi. 
Ahmad Samsul Bahri, Sri Sayekti Heni Sunaryanti, Daryanti (Hubungan Antara Pengetahuan, Sikap Dan Perilaku Perawat Dalam Mengatasi Stres Hospitalisasi Pada Anak Pra Sekolah Di Rumah Sakit Umum Fitri Candra Wonogiri)

\begin{abstract}
Background: Hospitalization in children is a process that occurs for a planned reason or an emergency that requires the child to stay in the hospital. Knowledge, attitudes ad goos behavior of nurses in overcoming the impact of hospitalization are expected to help overcome hospitalization stress in children

The Purpose: Knowing the realtionship between knowledge, attitude and behavior of nurses in dealing with hospitalizasion stress in pre-school children at Fitri Candra Wonogiri General Hospital

Method: The research method is correlation description, cross sectional approach. The study sample was 25 inpatient nurses and 25 pediatric patients with hospitaslization. The sample technique uses Saturated Sampling. The research instrument used a questionnaire of knowledge, attitudes and behavior, the stress level of hospitalization using DASS. Data analysis used Fisher exact statistical test and multiple linear regression.

Results: There were 16 respondents (64\%) with good knowledge, 9 respondents (36\%) with poor knowledge. There were 18 respondents (72\%) with a positive attitude, 7 respondents (28\%) with negative attitudes. ) with good behavior and 11 respondents (44\%) with poor behavior A total of 13 children with mild stress (52\%) and 12 respondents with moderate stress (48\%). Fisher exact test results relationship between knowledge and hospitalization stress $p=0.041$.

The relationship between attitude and hospitalization stress obtained $p=0.030$. The relationship between behavior and hospitalization stress obtained $p=0.047$. Linear regression equation multiple $Y=39,573$ - 0.629 X1-0,216X2-0,709X3.

Conclusion: There is a relationship between knowledge, attitudes and behavior of nurses in dealing with hospitalization stress in pre-school children. Nurse behavior factor is the most influencing factor on the stress level of pre-school children's hospitalization.
\end{abstract}

Keywords: Knowledge, attitudes, behavior, stress of hospitalization.

\title{
PENDAHULUAN
}

Hospitalisasi pada anak merupakan suatu proses yang terjadi karena suatu alasan yang direncanakan atau darurat sehingga mengharuskan anak untuk tinggal di rumah sakit.

Menurut WHO jumlah anak yang menjalani hospitalisasi tahun 2011 sebanyak 152 juta. Di Amerika Serikat, diperkirakan lebih dari 5 juta anak menjalani hospitalisasi karena prosedur pembedahan dan lebih dari 5\% dari jumlah tersebut, anak mengalami kecemasan dan stres. Diperkirakan juga lebih dari 1,6 juta anak dan anak usia antara 2-6 tahun menjalani hospitalisasi disebabkan karena injury dan berbagai penyebab lainnya.

Angka kesakitan anak di Indonesia berdasarkan Survei Kesehatan Nasional (Sunsenas) tahun 2010, di daerah perkotaan menurut kelompok usia 04 tahun sebesar $25,8 \%$, usia 5-12 tahun sebanyak 14,91. Anak yang dirawat di 
rumah sakit akan berpengaruh pada kondisi fisik dan psikologinya, hal ini disebut dengan hospitalisasi.

Berdasarkan data yang didapatkan dari Rekam Medik Rumah Sakit Umum Fitri Candra, pada tahun 2019 total keseluruhan anak yang dirawat sebanyak 325 anak. Untuk usia anak pra sekolah sebanyak 315 orang. Pada bulan Januari sampai Maret 2020 jumlah anak yang dirawat sebanyak 75 orang dan untuk anak usia pra sekolah sebanyak 48 orang. Hasil observasi pada 7 anak ditemukan menangis terutama saat dilakukan tindakan keperawatan. Selain menangis, anak banyak bergerak seperti kehilangan kontrol dan menghindar ketika akan dilakukan tindakan perawatan. Dari hasil survei yang dilakukan diruangan anak bahwa anak sering mengalami kecemasan ketika dirawat, anak menjadi sering gelisah, rewel dan harus ditemani ketika menjalani proses perawatan.

Di usia 0-5 tahun daya tahan tubuh anak masih lemah, sehingga anak mudah sakit dan menjalani perawatan. Saat menjalani perawatan berbagai perasaan muncul pada anak, yaitu cemas, marah, sedih, takut, dan merasa bersalah anak akan menunjukkan berbagai perilaku sebagai reaksi terhadap pengalaman hospitalisasi.

Pada saat hospitalisasi anak akan mengalami stres karena lingkungan yang asing bagi anak. Stres yang dialami anak akan menimbulkan banyak reaksi misalnya terhadap penyakit atau masalah diri anak pra sekolah seperti perpisahan, tidak mengenal lingkungan, hilangnya kasih sayang, body image maka akan beraksi seperti regresi yaitu hilangnya kontrol, displacement, agresi (menyangkal), menarik diri, tingkah laku protes, serta lebih antaranya mengalami ketakutan saat petugas kesehatan akan melakukan perawatan pada anak (Wahyuni, 2016).

Peran perawat dalam meminimalkan stres akibat hospitalisasi pada anak sangat penting. Perawat perlu memahami konsep stres hospitalisasi dan prinsipprinsip asuhan keperawatan melalui pendekatan proses keperawatan. Untuk dapat mengambil sikap sesuai dengan peran perawat dalam asuhannya meminimalkan kecemasan akibat hospitalisasi, perlu adanya pengetahuan sebelumnya tentang kecemasan hospitalisasi, karena keberhasilan suatu asuhan keperawatan sangat tergantung dari pemahaman dan kesadaran mengenai makna yang terkandung dalam konsep-konsep keperawatan serta harus memiliki pengetahuan, sikap dan keterampilan dalam menjalankan tugas sesuai dengan perannya.

RSU Fitri Candra awalnya adalah Rumah Sakit Bersalin, sehingga untuk pengalaman perawatnya masih dominan untuk merawat pasien Obsgyn, dan dalam menangani pasien anak masih belum mempunyai pengalaman yang banyak.

Berdasarkan latar belakang diatas, maka penulis tertarik untuk melakukan penelitian yang berjudul " Hubungan Antara Pengetahuan, Sikap dan Perilaku Perawat Dalam Mengatasi Stres Hospitalisasi Pada Anak Pra Sekolah Di Rumah Sakit Umum Fitri Candra Wonogiri”. 
Ahmad Samsul Bahri, Sri Sayekti Heni Sunaryanti, Daryanti (Hubungan Antara Pengetahuan, Sikap Dan Perilaku Perawat Dalam Mengatasi Stres Hospitalisasi Pada Anak Pra Sekolah Di Rumah Sakit Umum Fitri Candra Wonogiri)

\section{METODE PENELITIAN}

Metode penelitian adalah deskripsi kolerasi, pendekatan cross sectional. Sampel penelitian adalah 25 perawat Rawat Inap dan 25 pasien anak dengan hospitalisasi. Teknik sampel menggunakan Sampling Jenuh. Instrumen penelitian menggunakan kuesioner pengetahuan, sikap dan perilaku, tingkat stres hospitalisasi menggunakan DASS. Analisis data menggunakan uji statistik Fisher exact dan regresi Linier berganda

\section{HASIL DAN PEMBAHASAN}

\section{Hasil}

Tabel 1 Distribusi karakteristik responden berdasarkan jenis kelamin perawat, usia, pendidikan terakhir, masa kerja, dan jenis kelamin anak pra sekolah

\begin{tabular}{|c|c|c|c|}
\hline No & Jenis kelamin perawat & Jumlah & Presentase (\%) \\
\hline \multirow[t]{2}{*}{1.} & Laki - Laki & 5 & 20 \\
\hline & Perempuan & 20 & 80 \\
\hline \multirow[t]{4}{*}{2.} & Usia perawat & & \\
\hline & 17-25 tahun & 13 & 52 \\
\hline & 26-35 tahun & 8 & 32 \\
\hline & 36-46 tahun & 4 & 16 \\
\hline \multirow[t]{3}{*}{3.} & Pendidikan terakhir & & \\
\hline & D3 Keperawatan & 91 & 76 \\
\hline & S.Kep.,Ners & 6 & 24 \\
\hline \multirow[t]{4}{*}{4.} & Pengalaman Kerja & & \\
\hline & $1-5$ tahun & 19 & 76 \\
\hline & 6-10 tahun & 2 & 8 \\
\hline & 11-15 tahun & 4 & 16 \\
\hline \multirow[t]{3}{*}{5.} & Jenis kelamin anak pra sekolah & & \\
\hline & Laki-laki & 13 & 52 \\
\hline & Perempuan & 12 & 48 \\
\hline
\end{tabular}

Tabel 2 Distribusi frekuensi responden berdasarkan tingkat Pengetahuan perawat dalam mengatasi stres hospitalisasi pada anak_pra sekolah

\begin{tabular}{ccc}
\hline Tingkat Pengetahuan & Frekuensi & Persentase (\%) \\
\hline Baik & 16 & 64 \\
Cukup & 0 & 0 \\
Kurang baik & 9 & 36 \\
Total & 25 & 100 \\
\hline
\end{tabular}


Ahmad Samsul Bahri, Sri Sayekti Heni Sunaryanti, Daryanti (Hubungan Antara Pengetahuan, Sikap Dan Perilaku Perawat Dalam Mengatasi Stres Hospitalisasi Pada Anak Pra Sekolah Di Rumah Sakit Umum Fitri Candra Wonogiri)

Tabel 3 Distribusi frekuensi responden berdasarkan perilaku perawat dalam mengatasi stres hospitalisasi pada anak pra

\begin{tabular}{ccc}
\hline Perilaku & Frekuensi & Persentase (\%) \\
\hline Baik & 14 & 56 \\
Cukup & 0 & 0 \\
Kurang baik & 11 & 44 \\
Total & 25 & 100 \\
\hline
\end{tabular}

Tabel 4 Distribusi frekuensi responden berdasarkan stres hospitalisasi pada anak pra sekolah

\begin{tabular}{ccc}
\hline Stres hospitalisasi & Frekuensi & Persentase (\%) \\
\hline Tidak stres & 0 & 0 \\
Stres ringan & 13 & 52 \\
Stres sedang & 12 & 48 \\
Stres berat & 0 & 0 \\
Total & 25 & 100 \\
\hline
\end{tabular}

Tabel 5 Hubungan Tingkat Pengetahuan Perawat dalam Mengatasi Stres Hospitalisasi pada Anak Pra Sekolah.

\begin{tabular}{|c|c|c|c|c|c|c|c|c|}
\hline \multirow{4}{*}{$\begin{array}{c}\text { Pengetahuan } \\
\text { Baik }\end{array}$} & \multicolumn{6}{|c|}{ Stress Hospitalisasi } & $\mathrm{p}$ & Keputusan \\
\hline & Rin & $\operatorname{san}$ & $\mathrm{Se}$ & ang & & tal & \multirow{5}{*}{0,041} & \multirow{5}{*}{ Ho ditolak } \\
\hline & $\mathrm{n}$ & $\%$ & $\mathrm{n}$ & $\%$ & $\mathrm{n}$ & $\%$ & & \\
\hline & 11 & 44 & 5 & 20 & 16 & 64 & & \\
\hline Kurang Baik & 2 & 8 & 7 & 8 & 9 & 36 & & \\
\hline Total & 13 & 52 & 12 & 48 & 25 & 100 & & \\
\hline
\end{tabular}

Berdasarkan tabel diatas diketahui perawat dengan pengetahuan yang baik dalam mengatasi stres hospitalisasi cenderung manjadikan anak Hospitalisasi mengalami stres ringan, sedankan perawat dengan pengetahuan yang kurang baik, stres anak pra sekolah cenderung mengalami stres sedang. Hasil uji statistik dengan Fischer Exact diperoleh nilai $\mathrm{p}=0,041 \quad(\mathrm{p}<0,05)$ sehingga hipotesa penelitian yang diambil adalah Ho ditolak. Ho ditolak artinya ada Hubungan Tingkat Pengetahuan Perawat dalam Mengatasi Stres Hospitalisasi pada Anak Pra Sekolah. 
Ahmad Samsul Bahri, Sri Sayekti Heni Sunaryanti, Daryanti (Hubungan Antara Pengetahuan, Sikap Dan Perilaku Perawat Dalam Mengatasi Stres Hospitalisasi Pada Anak Pra Sekolah Di Rumah Sakit Umum Fitri Candra Wonogiri)

Tabel 6 Hubungan sikap Perawat dalam Mengatasi Stres Hospitalisasi pada Anak Pra Sekolah

\begin{tabular}{|c|c|c|c|c|c|c|c|c|}
\hline \multirow{4}{*}{$\begin{array}{c}\text { Sikap Perawat } \\
\text { Positif }\end{array}$} & \multicolumn{6}{|c|}{ Stress Hospitalisasi } & $\mathrm{p}$ & Keputusan \\
\hline & Rir & $\operatorname{gan}$ & $\mathrm{Sec}$ & & & tal & \multirow{5}{*}{0,03} & \multirow{5}{*}{ Ho ditolak } \\
\hline & $\mathrm{n}$ & $\%$ & $\mathrm{n}$ & $\%$ & $\mathrm{n}$ & $\%$ & & \\
\hline & 12 & 44 & 6 & 24 & 18 & 72 & & \\
\hline Negatif & 1 & 8 & 6 & 24 & 7 & 28 & & \\
\hline Total & 13 & 52 & 12 & 48 & 25 & 100 & & \\
\hline
\end{tabular}

Berdasarkan tabel diatas menunjukkan sikap perawat yang positif cenderung menjadikan anak mengalami stres hospitalisasi kategori ringan, sedangkan perawat dengan sikap yang negatif, cenderung menjadikan anak mengalami stres hospitalisasi kategori sedang. Hasil uji statistik dengan Fischer Exact diperoleh nilai $\mathrm{p}=0,030(\mathrm{p}<0,05)$ sehingga hipotesa penelitian yang diambil adalah Ho ditolak. Ho ditolak artinya ada hubungan sikap perawat dalam mengatasi stres hospitalisasi pada anak pra sekolah.

Tabel 7 Hubungan perilaku Perawat dalam Mengatasi Stres Hospitalisasi pada Anak Pra Sekolah

\begin{tabular}{ccccccccc}
\hline & \multicolumn{1}{c}{ Stress Hospitalisasi } & & $\mathrm{p}$ & Keputusan \\
\hline & Ringan & \multicolumn{2}{c}{ Sedang } & \multicolumn{2}{c}{ Total } & & \\
Perilaku Perawat & $\mathrm{n}$ & $\%$ & $\mathrm{n}$ & $\%$ & $\mathrm{n}$ & $\%$ & & \\
Baik & 10 & 40 & 4 & 16 & 14 & 56 & 0,047 & Ho ditolak \\
Kurang Baik & 3 & 12 & 8 & 32 & 11 & 44 & & \\
Total & 13 & 52 & 12 & 48 & 25 & 100 & & \\
\hline
\end{tabular}

Berdasarkan tabel diatas menunjukkan perilaku perawat yang baik cenderung menjadikan anak mengalami stres perawat dengan perilaku yang kurang baik, cenderung menjadikan anak mengalami stres hospitalisasi kategori sedang. Hasil uji statistik dengan Fisher Exact diperoleh nilai p=0,047( $p<0,05)$ sehingga hipotesa yang diambil adalah Ho ditolak.

Artinya ada hubungan antara perilaku perawat dalam mengatasi stress hospitalisasi pada anak pra sekolah.

Tabel 8 Hasil uji regresi linier berganda

\begin{tabular}{cccc}
\hline Variabel & $\beta$ & t test & $\mathrm{p}$ \\
\hline (Constan) $\alpha$ & 39,573 & 2,951 & 0,000 \\
Pengetahuan $\left(\mathrm{X}_{1}\right)$ & $-0,629$ & $-4,638$ & 0,000 \\
Sikap $\left(\mathrm{X}_{2}\right)$ & $-0,216$ & $-3,107$ & 0,005 \\
Perilaku $\left(\mathrm{X}_{3}\right)$ & $-0,709$ & $-2,423$ & 0,025 \\
$F$ test & 19,320 & & 0,000 \\
Adjusted $\mathrm{R}^{2}$ & 0,696 & & \\
\hline
\end{tabular}


Berdasarkan tabel diatas, maka dapat dibuat persamaan regresi linier berganda sebagai berikut:

$$
\bar{Y}=\alpha+\beta_{1} X_{1}+\beta_{2} X_{2}+\beta_{3} X_{3}
$$

Maka hasil dari uji regresi dari tabel 8 adalah

$\bar{Y}=39,573-0,629 X_{1}-0,216 X_{2}-0,709 X_{3}$

Interprestasi dari angka-angka koefisien persamaan regresi tersebut diatas adalah:

Nilai konstanta $\alpha=\mathbf{3 9 , 5 7 3}$; artinya apabila nilai variabel bebas ( pengetahuan, sikap dan perilaku) sama dengan nol, maka tingkat stress sebesar 39,573, menjadikan anak stress kategori ringan, sedangkan nilai Koefisien $\beta_{1}=\mathbf{- 0 , 6 2 9}$, artinya variabel pengetahuan mempunyai hubungan negatif dengan stress hospitalisasi anak pra sekolah Apabila tingkat pengetahuan perawat baik maka akan mengakibatkan stres hospitalisasi anak usia pra sekolah menurun sebasar 0,629. Nilai koefisien $\beta_{2}=\mathbf{- 0 , 2 1 6}$; artinya variabel sikap perawat mempunyai hubungan negatif dengan stres hospitalisasi anak usia pra sekolah. Apabila sikap perawat semakin positif maka akan mengakibatkan stres hospitalisasi anak usia pra sekolah menurun sebasar $\mathbf{0 , 2 1 6}$. Nilai koefisien $\beta_{3}=\mathbf{- 0 , 7 0 9}$; artinya variabel perilaku perawat mempunyai hubungan negatif dengan stres hospitalisasi anak usia pra sekolah. Apabila perilaku perawat semakin baik maka akan mengakibatkan stres hospitalisasi anak usia pra sekolah menurun sebasar 0,709.

\section{Pembahasan}

Berdasarkan hasil penelitian tingkat Tingkat pengetahuan perawat dalam mengatasi stres hospitalisasi anak pra sekolah 64\% dalam kategori baik. Kategori baik dalam pengetahuan responden dapat diartikan perawat sudah mempunyai pengetahuan yang baik tentang cara-cara mengatasi stres hospitalisasi anak pra sekolah.

Menurut Notoadmojo (2016), tingkat pengetahuan sesorang melalui 6 tahapan, yaitu tahu, memahami, aplikasi, analisis, sintesis dan evaluasi. Pengetahuan yang baik ini tidak sekedar tahu, dan memahami, tetapi sudah dalam tahap aplikasi, sintesis maupun evaluasi.

Hasil penelitian Damaiyanti (2019) menyebutkan ada hubungan tingkat kecemasan dengan kinerja perawat di rumah sakit Atma Husada Mahakam Hospital, Samarinda. Kinerja yang baik dipengaruhi oleh tingkat pengetahuan perawat dengan baik.

Berdasarkan hasil penelitian diketahui $72 \%$ sikap perawat dalam mengatasi stres hospitalisasi anak pra sekolah dalam kategori positif. Sikap positif mencerminkan sikap perawat yang peduli dalam perawatan anak usia pra sekolah dengan hospitalisasi agar anak tidak mengalami stres selama perawatan di rumah sakit.

Menurut Notoadmojo (2016) bahwa sikap seseorang dapat dipengaruhi oleh tingkat pengetahuan. Orang yang mempunyai pengetahuan yang baik akan mengarah pada sikap yang baik atau positif. Azwar (2014) menyatakan 
faktor yang mempengaruhi pembentukan sikap manusia antara lain pengaruh orang lain yang dianggap penting.

Penelitian Siagian (2020) menyebutkan 70,83 \% perawatan memiliki sikap kategori sedang dalam perawatan paliatif di rumah sakit Advent Bandar Lampung.

Berdasarkan hasil penelitian diketahui $56 \%$ perilaku perawat dalam mengatasi stres hospitalisasi anak pra sekolah dalam kategori baik. Menurut Notoadmojo (2016) perilaku merupakan respons atau reaksi seseorang terhadap stimulus (rangsangan dari luar). Oleh karena itu perilaku ini terjadi melalui proses adanya stimulus terhadap organisme, dan kemudian organisme tersebut merespons, maka teori skinner ini disebut "S-O-R" atau Stimulus Organisme Respons. Skinner membedakan adanya dua respons.

Penelitian Aeni (2019) menjelaskan 53,1\% perawat yang telah menerapkan perilaku caring membuat pasien merasa puas dengan asuhan yang diberikan dalam penelitian di Rumah Sakit Kabupaten Indramayu.

Hasil penelitian Stres hospitalisasi anak pra sekolah diketahui 52\% anak mengalami stres ringan. Wong (2012), menjelaskan penyakit dan hospitalisasi sering kali menjadi krisis pertama yang harus dihadapi anak. Anak-anak sangat rentan terhadap krisis penyakit dan hispitalisasi kerena stress akibat perubahan dari keadaan sehat biasa dan rutinitas lingkungan. Stres utama dari hospitalisasi adalah perpisahan, dan maupun rasa nyeri yang dirasakan. Hasil penelitian yang dilakukan Sartika (2017) hospitalisasi mempengaruhi tingkat kecemasan anak toddler diketahui 87,3\% tidak mengalami cemas, 12,7\% anak mengalami cemas. Tidak adanya kecemasan pada anak toddler disebabkan anak didampingi oleh orang tua saat hospitalisasi, lingkungan ruang perawatan yang aman dan nyaman da adanya perlengakapan permainan, mengakibatkan anak toddler dapat melakukan koping adaptif dengan baik.

Berdasarkan hasil penelitian bahwa stres anak dengan hospitalisasi terjadi karena takut berpisah dengan orang tua, takut pada saat pemeriksaan kesehatan. Reaksi yang timbul seperti menangis, sulit makan. Namun pada saat penelitian diketahui bahwa anak dengan stres ringan disebabkan anak dalam kondisi ditemani orang tua, mau berkomunikasi dengan orang lain, dan bahkan sudah dapat memahami proses pengobatan selama di rumah sakit.

Hasil analisis uji statistic bivariat pada data hubungan tingkat pengetahuan perawat dengan stres hospitalisasi anak pra sekolah diperoleh nilai $\mathrm{p}=0,041$, sehingga disimpulkan ada hubungan tingkat pengetahuan perawat dengan stres hospitalisasi anak pra sekolah.

Wong et al, (2014), mengemukakan penyakit dan hospitalisasi sering kali menjadi krisis pertama yang harus dihadapi anak. Hospitalisasi akan menyebabkan anak mengalami trauma baik jangka pendek ataupun jangka panjang. Dampak negatif ini berkaitan dengan lamanya perawatan, prosedur invasive yang harus dijanali pasien, cemas terhadap perpisahan, ketakutan, serta gangguan tidur. Pendapat Pott dan \& Modleco (2017) menyatakan bahwa anak yang mengalami gangguan psikologis akibat perpisahan akan menunjukan sakit kepala, mual, muntah, demam ringan, gelisah, kelelahan, sulit berkonsentrasi, mudah marah. 
Adanya stres hospitalisasi pada anak, maka perawat dalam melakukan asuhan keperawatan untuk membantu menurunkan stres hospitalisasi didasarkan pada pengetahuan yang dimilikinya.

Notoatmodjo (2016), menyatakan pengetahuan merupakan hasil dari tahu, dan ini terjadi setelah orang melakukan penginderaan terhadap suatu objek tertentu. Berdasarkan data pada tabulasi silang diketahui bahwa perawat dengan pengetahuan yang baik menjadikan stres hospitalisasi cenderung ringan, sementara pengetahuan perawat yang kurang baik menjadikan stres hospitalisasi anak dalam kategori sedang. Oleh karena itu semakin baik pengetahuan perawat yang baik berdampak pada tingkat stres pada anak. Hasil penelitian ini juga memperkuat penelitian sebelumnya yang dilakukan oleh Sari (2017) yang menyebutkan ada hubungan antara pengetahuan dengan dampak hospitalisasi pada anak pra sekolah di ruang rawat inap Rumah Sakit Islam Malahayati.

Hasil analisis hubungan sikap perawat dengan stres hospitalisasi anak pra sekolah diperoleh nilai $\mathrm{p}=0,030$, sehingga disimpulkan ada hubungan sikap perawat dengan stres hospitalisasi anak pra sekolah. Perawat dengan sikap positif cenderung menjadikan stres hospitalisasi anak pra sekolah menjadi ringan.

Notoadmojo (2016) sikap adalah konsep penting dalam psikologis sosial, sikap adalah kecenderungan untuk bertindak, bersepsi, serta berpikir dan merasakan situasi dan nilai. Sikap bukan merupakan perilaku, tetapi merupakan kecenderungan untuk berperilaku dengan cara tertentu terhadap objek sikap. Sikap ramah terhadap anak selama hospitaslisasi menjadikan anak merasa diperhatikan kebutuhannya, sehingga rasa takut berpisah

dengan orang tua, takut pada lingkungan baru dapat menjadi berkurang dengan kehadiran perawat dengan sikap positif dalam melakukan asuhan keperawatan.

Sikap positif yang ditunjukkan perawat juga didasarkan atas pengetahuan dan pengalaman sebelumnya dalam melakukan asuhan keperawatan anak. Oleh karena itu sikap positif perawat dapat menjadikan stres hospitaslisasi anak menjadi ringan. Hasil penelitian serupa dilakukan oleh Hulinggi (2018) bahwa sikap yang positif dapat membantu menurunkan stres hospitasasi anak di RSU Pancaran Kasih GMIM Manado.

Hasil analisis hubungan perilaku perawat dengan stres hospitalisasi anak pra sekolah diperoleh nilai $\mathrm{p}=0,047$, sehingga disimpulkan ada hubungan perilaku perawat dengan stres hospitalisasi anak pra sekolah. Perawat dengan perilaku yang baik dapat membantu menurunkan stres hospitalisasi anak pra sekolah menjadi ringan.

Lidia (2013) salah satu tugas perawat adalah melaksanakan tugas memberi asuhan keperawatan dengan perilaku caring. perawat yang berperilaku caring berarti perawat tersebut mampu mengurangi stress ataupun trauma pasien ketika menjalani hospitalisasi. Perawat yang memiliki sifat caring adalah perawat yang memiliki kualitas kepribadian yang baik.

Penerapan periku yang baik pada perawat didasari atas, pengetahuan yang baik, sikap yang sabar dan tenang, memiliki rasa humor, penuh kasih sayang. Pendekatan secara humanis kepada anak dengan hospitalisasi yang mengalami 
stres dapat membantu untuk menerima kondisi sakit selama perawatan di rumah sakit. Hasil penelitian serupa dilakukan oleh Suparno (2019) yang menjelaskan ada hubungan perilaku caring perawat dengan stress hospitalisasi pada anak usia prasekolah di Ruang Rawat Inap di RSUD Dr.Ibnu Soetowo Baturaja. Perilaku caring perawat yang baik akan meminimalkan stress hospitalisasi pada anak usia pra sekolah.

Hasil analisis uji regresi linier berganda diperoleh nilai $\mathrm{F}$ test $=19,320$ dengan signifikansi $\mathrm{p}<0,000$, sehingga disimpulkan ada hubungan signifikan antara pengetahuan, sikap dan perilaku perawat dalam mengatasi stres hospitalisasi pada anak pra sekolah di Rumah Sakit Umum Fitri Candra Wonogiri.

Domain perilaku berdasarkan dari teori Bloom dalam Notoadmojo (2016) perilaku dibagi menjadi tiga yaitu pengetahuan (knowledge), sikap (attitude), dan praktik (practice). Pengetahuan perawat yang baik

dapat dipengaruhi oleh faktor lain seperti tingkat pendidikan. Berdasakan hasil penelitian diketahui pendidikan perawat sebagian besar adalah lulusan D3 Keperawatan.

Berbekal pengetahuan yang baik menjadikan sikap perawat juga menjadi positif. Menurut Eagle dan Chaiken (1993) dalam. Wawan dan Dewi (2010) mengemukakan bahwa sikap dapat diposisikan sebagai hasil evaluasi terhadap obyek yang diekspresikan ke dalam proses- proses kognitif, afektif (emosi) dan perilaku. Sikap yang positif ini terlihat bagaimana perawat bersikap ramah, dan terbuka dalam komunikasi baik kepada orang tua pasien maupun pasien itu sendiri. Sikap yang positif ini diwujudkan dalam perilaku perawat. Selama perawatan anak, perawat melakukan upaya-upaya untuk membantu anak yang mengalami stres.

Salah satu upaya yang dapat dilakukan untuk membantu menurunkan rasa stres adalah dengan mengajak berbicara tentang suatu cerita dongeng atau cuplikan film-film yang anak sukai. Somantri (2016), menjelaskan bercerita tentang anak merupakan suatu kegiatan menyampaikan secara lisan pada pendengar dengan menggunakan gaya tertentu yang menarik perhatian. Sue (2010) berpendapat dalam bercerita akan terjadi proses reframing dimana pasien secara tidak sadar mengontrol pikiran negatif mereka dengan

cara mengubah pandangan mereka ke arah yang lebih positif dengan cara mendengarkan cerita dari perawat. Pasien yang mau mendengarkan cerita dari perawat secara tidak lansung dapat menurunkan stres yang dirasakan anak.

Penelitian ini sejalan dengan penelitian yang dilakukan oleh Dewi (2017) dengan judul pengetahuan, sikap dan tindakan perawat dengan tingkat kecemasan hospitalisasi anak pra sekolah, dengan hasil penelitian terdapat hubungan pengetahuan, sikap dan tindakan perawat dengan tingkat kecemasan hospitalisasi pada anak prasekolah di ruang rawat anak RSUD Dr. Zainoel Abidin dan RSUD Meuraxa Banda Aceh. 
Ahmad Samsul Bahri, Sri Sayekti Heni Sunaryanti, Daryanti (Hubungan Antara Pengetahuan, Sikap Dan Perilaku Perawat Dalam Mengatasi Stres Hospitalisasi Pada Anak Pra Sekolah Di Rumah Sakit Umum Fitri Candra Wonogiri)

\section{SIMPULAN DAN SARAN}

\section{Simpulan}

Tingkat pengetahuan perawat dalam mengatasi stres hospitalisasi pada anak pra sekolah di Rumah Sakit Umum Fitri Candra Wonogiri sebagian besar dalam kategori baik (64\%). Sikap perawat dalam mengatasi stres hospitalisasi pada anak pra sekolah di Rumah Sakit Umum Fitri Candra Wonogiri sebagian besar dalam kategori positif (72\%). Perilaku perawat dalam mengatasi stres hospitalisasi pada anak pra sekolah di Rumah Sakit Umum Fitri Candra Wonogiri sebagian besar dalam kategori baik (56\%). Tingkat stres hospitalisasi pada anak pra sekolah di Rumah Sakit Umum Fitri Candra Wonogiri sebagian besar dalam kategori ringan $(52 \%)$.

Ada hubungan pengetahuan perawat dalam mengatasi stres hospitalisasi pada anak pra sekolah di Rumah Sakit Umum Fitri Candra Wonogiri $(p=0,041)$ Ada hubungan sikap perawat dalam mengatasi stres hospitalisasi pada anak pra sekolah di Rumah Sakit Umum Fitri Candra Wonogiri $(\mathrm{p}=0,030)$ Ada hubungan perilaku perawat dalam mengatasi stres hospitalisasi pada anak pra sekolah di Rumah Sakit Umum Fitri Candra Wonogiri ( $\mathrm{p}=0,047)$ Ada hubungan pengetahuan, sikap dan perilaku perawat dalam mengatasi stres hospitalisasi pada anak pra sekolah di Rumah Sakit Umum Fitri Candra Wonogiri $(p=0,000)$

\section{Saran}

Bagi masyarakat, diharapkan mengenali gambaran tentang pengetahuan, sikap, dan perilaku perawat dalam mengatasi stres hospitalisasi pada anak pra sekolah sehingga dapat melakukan antisipasi dalam membantu tenaga kesehatan mengurangi stress anak pra sekolah dengan hospitalisasi di rumah sakit. Bagi tenaga kesehatan, diharapkan dapat menambah pengetahuan dan ketrampilan perawat dalam mengatasi stres hospitalisasi pada anak pra sekolah. Bagi pengetahuan ilmu kesehatan, diharapkan dapat mengembangkan khasanah ilmu pengetahuan secara teoritis tentang hubungan antara pengetahuan, sikap dan perilaku perawat dalam mengatasi stress akibat hospitalisasi pada anak usia pra sekolah. Hasil penelitian ini masih dapat dikembangkan lagi bagi peneliti selanjutnya tentang stres hospitalisasi pada anak pra sekolah dengan metode penelitian lain dan variabel lain seperti riwayat penyakit, sibling, lama perawatan sehingga memperoleh hasil penelitian yang lebih baik lagi.

\section{DAFTAR PUSTAKA}

A. Wawan dan Dewi, 2010, Teori dan Pengukuran Pengetahuan, Sikap dan Perilaku Manusia, Yogyakarta : Nuha Medika

Aeni, W. N, 2019 Pengaruh Ketua Tim Terhadap Kinerja Perawat di Kabupaten Indramayu. Vol 7 No 1, Januari 2019 - Juni 2019

Azwar, S, 2015, Penyusunan Skala Psikologi Edisi 2. Yogyakarta: Pustaka. Belajar 
Ahmad Samsul Bahri, Sri Sayekti Heni Sunaryanti, Daryanti (Hubungan Antara Pengetahuan, Sikap Dan Perilaku Perawat Dalam Mengatasi Stres Hospitalisasi Pada Anak Pra Sekolah Di Rumah Sakit Umum Fitri Candra Wonogiri)

Damaiyanti, M, 2019, Hubungan Antara Kecemasan Dengan Kinerja Perawat di RS. Jiwa Atma Husada Mahakam Samarinda. Jurnal Ilmu Kesehatan Vol 7 No 12019

Dewi, P, Sufriani, 2017, Pengetahuan, Sikap Dan Tindakan Perawat Dengan Tingkat Kecemasan Hospitalisasi Anak Prasekolah. Jurnal Keperawatan Banda Aceh. Volume 1 Nomer 2, 2017

Hulinggi I, 2018, Hubungan Sikap Perawat dengan Stres Akibat Hospitalisasi pada Anak Usia Pra Sekolah di RSU Pancaran Kasih GMIM Manado. ejournal Keperawatan (e-Kp) Volume 6 Nomor 1, Mei 2018

Herlia Sumardha Nasution, Diwan Risfan Sari, 2017, Hubungan Pengetahuan Dengan Sikap Perawat Terhadap Dampak Hospitalisasi Pada Anak Pra Sekolah Di Ruang Rawat Inap Rumah Sakit Islam Malahayati. Jurnal Ilmiah Umum Dan Kesehatan, Vol: 4, No 1, Sekolah Tinggi Ilmu Kesehatan RS Haji Medan

Lidia G, Y. I, 2013, Hubungan Perilaku Caring Perawat Dengan Stres Hospitalisasi Pada Anak Usia Toddler Di Irina E BLU RSUP Prof. Dr. R. D. Kandou Manado. EJurnal Keperawatan, Volume 1 No 1

Notoatmodjo, S, 2016, Pendidikan dan Perilaku Kesehatan. Jakarta. Rineka Cipta.

Potts \& Mandleco, 2017, Pediatric Nursing; Caring for Children and Their Families. 3rd ed. Clifton Park. New York

Sartika, Z, 2017, Hospitalisasi Mempengaruhi Tingkat Kecemasan Anak Toddler. Vol. 3 No. 2, 2017

Siagian, E, 2020, Pengetahuan dan Sikap Perawat tentang Perawatan Paliatif di Rumah Sakit. Indonesian Nursing Scientific Journal. Volume 10, Nomer 03, 2020

Somantri, I, 2016, Efektifitas Terapi Mendongeng Terhadap Kecemasan Anak Usia Toddler dan Prasekolah Saat Tindakan Keperawatan. Jurnal Keperawatan Padjadjaran, Volume 4 Nomor 3, Desember 2016

Sue, D.C, 2010, Fundamentals of nursing: Standards \& practice, (2nd Ed.). New York: Delmar

Suparno, 2019, Hubungan Perilaku Caring Perawat dengan Stress Hospitalisasi Pada Anak Usia Pra Sekolah di Ruang Rawat Inap RSUD Dr. Ibnu Soetowo Baturaja. Jurnal Keperawatan Sriwijaya, Volume 6 - Nomor 1, Januari 2019,

Wong D. L., Huckenberry M.J, 2014, Wong's Nursing care of infants and hildren. Mosby Company, St Louis 